\title{
THE EFFECT OF PROTEIN ON THE CARBOHYDRATE TOLERANCE OF TWO CASES HAVING COMBINED DIABETES MELLITUS AND PERNICIOUS ANEMIA ${ }^{1}$
}

\author{
By NORMAN JOLLIFFE, HAROLD BRANDALEONE, AND HARRY MOST \\ (From the Department of Medicine, New York University College of Medicine, and the \\ Psychiatric Medical Service of the Third (New York University) Medical \\ Division, Bellevue Hospital, New York)
}

We have studied two subjects having both diabetes mellitus and pernicious anemia during a six and nine months' period of hospitalization. This combination of diseases has been recently reviewed by Root (1).

Marked fluctuations in carbohydrate tolerance were observed to follow changes in protein content of the diet. It is well known that the composition of the diet of the normal (2) as well as of the diabetic patient plays an important part in the carbohydrate tolerance. It is generally recognized (3) that the adult diabetic does best on a diet containing 0.66 to 1.0 gram of protein per kilogram of body weight per diem. The use of limited amounts of protein in the diets is so universal that the reason for its curtailment is often forgotten. Consequently, in the therapy of diseases complicating diabetes the tendency has been to give the diet prescribed for the complicating disease and if glycosuria occurs to control it with insulin. If this complicating disease is one in which a high protein diet is advisable, such as pernicious anemia, a real danger exists. The carbohydrate tolerance of these subjects, already impaired, may be seriously damaged.

Prior to the method of treatment by undernutrition, diabetic patients were placed on a diet consisting entirely of protein and fat. As Joslin (3) expresses it, these patients were "urged to devour, not merely eat, protein and fat ad libitum." In consequence, there were no mild diabetics among those so treated. The mildly diabetic, due to lack of carbohydrate in the diet and the excess of protein and fat, were made moderately severe. The moderately severe became severe, while the latter died in ketosis or barely escaped with their lives. During the era of undernutrition, patients were maintained aglycosuric whose

\footnotetext{
1 Presented in abstract before the Interurban Clinical Club, New York, December, 1934.
}

urine had never before been consistently sugar free, and the average duration of life of the diabetic increased. The success of this treatment must be credited to undernutrition and the sharp curtailment of protein in the diet. Falta and Gigon (4) in 1907 noted that an increase in protein of the diet of a severe diabetic caused more glycosuria than an increase in carbohydrate. Klemperer (5) showed that even dextrose could be assimilated to a considerable degree by a severe diabetic patient provided the protein in the diet was low.

The rapidity with which the effect of an excess of protein when given with a low carbohydrate, high fat diet manifests itself was demonstrated by a case reported by Gephart, Aub, DuBois, and Lusk (6). This patient's urine was sugar free on a diet of C. 40 to 50 grams, P. 94 grams and F. about 100 grams. He complained so bitterly that the diet was changed to C. 3 grams, P. 156 grams and F. 230 grams, giving double the calories and approximately the same carbohydrate equivalent. On the second day of this diet the $\mathrm{D}: \mathrm{N}$ ratio was 3.48. The deleterious effect of this diet may have been caused by increase in protein, an increase in fat, or by an increase in total calories. Evidence that the deleterious effect of this type of diet was due chiefly to the excess protein was presented by Geyelin and DuBois (7). In their patient, on a diet of C. 51 grams, P. 54 grams, F. 56 grams, the $D: N$ ratio averaged 1.81. A single day on a diet of C. 23.5 grams, P. 118.6 grams, F. 41 grams, which was isocaloric with the preceding diet, and contained 10 grams more available carbohydrate, resulted in a $\mathrm{D}: \mathrm{N}$ ratio of 3.97. The following day the diet was rearranged to C. 0.4 gram, P. 99 grams. F. 5.6 grams, almost halving the calories and reducing the available carbohydrate to below that in the original diet; the $D: N$ ratio became 4.01 . This case demonstrates that the increase in severity was not due to increase in total calories, 
fat, or in available carbohydrate. It demonstrates that the moderately severe diabetic may be converted into a severe diabetic by an increase in protein. Confirmation of the damaging effect of excess protein may be read in the work of Wilder, Boothby, and Beeler (8). Lusk (9) calls it "as clear-cut a piece of metabolism artistry as may well be conceived." These authors showed that the sugar tolerance is depressed by an increase in total calories, but more markedly depressed by an increase in protein than by isocaloric amounts of fat. They further state that the protein effect is not due to the sugar or ketogenic bodies derived from the protein but to " some other more specific action of protein, the result of which is to interfere with the mechanism of sugar utilization."

Recently Schloss (10) has presented evidence which indicates that high protein diets may not necessarily be harmful in some individuals. However, results presented in a second paper (11) indicate that glycosuria was greater on a high protein than on a high fat diet, whether preceded or followed by the latter.

Von Noorden (12), Falta and Gigon (4), and Joslin (3) emphasized the danger of excess protein in the diet in diabetes mellitus. Woodyatt (13) demonstrated the necessity for keeping diabetics on a diet containing enough calories to prevent consumption of body protein. He emphasized that when the patient is forced to fall back on his own tissues for food he can draw only upon the materials that are there; if fat is not present the protein burns. Excessive consumption of body protein may explain some of the failures of treatment by the method of undernutrition.

Newburgh and Marsh (14) effectively demonstrated this point in a group of 43 diabetics. Their diet consisted of C. 10 to 30 grams, P. 10 to 40 grams, and F. 20 to 175 grams. The upper margin for fat in grams when placed at twice the carbohydrate plus one-half the protein was well exceeded in all their diets. They demonstrated that a diabetic subject may be expected to become and remain sugar free without acidosis on a high fat diet containing sufficient calories to prevent undernutrition provided the protein was low.

From the available literature on the effect of protein in the diabetic's diet it has been demonstrated :

1. That pure protein-fat diet is extremely deleterious.

2. On low carbohydrate diets an increase in protein as a rule increases the severity of the diabetes out of all proportion to the extra sugar derived from protein.

3. Isocaloric increases in protein are generally more harmful than isocaloric increases in fat.

4. That acidosis does not occur when the ketogenic-anti-ketogenic ratio is exceeded provided the protein is minimal.

Will the high carbohydrate diet protect, delay, or minimize the deleterious action of an excess protein in the diet of the diabetic? Will the deleterious effects of excess protein be manifest if long continued or severe glycosuria be prevented? Will the impaired tolerance be permanent? We believe the study of our two cases indicates the answer to these questions.

\section{CASE REPORTS}

Case I

M. K., a 59 year old native white widow, was admitted to the medical wards of the Bellevue Psychiatric Division on September 28, 1933. She was admitted to another hospital earlier the same day, but showed mental symptoms and was immediately transferred to this hospital. On admission no history was obtained; she was semi-comatose, with a heavy odor of acetone on the breath and evidence of dehydration and emaciation. The breathing was of the Kussmaul type. Urine contained much acetone and diacetic acid and 3 per cent sugar. The blood sugar was $375 \mathrm{mgm}$. per cent, and nonprotein nitrogen $39 \mathrm{mgm}$. per cent. Treatment for diabetic ketosis was immediately instituted with the result that the patient was alert and cooperative in four hours and the urine free from acetone in seven hours. Further examination revealed a marked pallor, smooth tongue and signs of well advanced combined system disease of the spinal cord. The blood count was 1.9 million red cells, hemoglobin 6.4 grams per $100 \mathrm{cc}$. Study of the stained smear revealed marked oval macrocytosis. The total leukocyte count was 3,100 , with a differential formula of polymorphonuclear leukocytes 77 , lymphocytes 23 , monocytes 0. Gastric analysis, using the alcohol test meal and followed by histamine, showed absence of free hydrochloric acid and extremely low total acidity. Stool examinations were negative for ova, parasites or blood. Roentgen studies of the gastro-intestinal tract were negative.

Following recovery from the ketosis the following 
pertinent history was obtained: In 1928 the patient had developed symptoms of weakness and paresthesias, for which she had entered another hospital. While there she was considered to have Addisonian pernicious anemia, and a remission was induced by administration of liver extract. Following discharge she continued to take a diet rich in green vegetables and meats, with liver twice a week. She remained in good health until June, 1933, when she lost her appetite and stopped eating liver and meat. A month later she noted return of weakness and paresthesias and loss of weight. Polyuria and polydypsia began two weeks prior to admission, and one week before admission she was told she had diabetes. At this time the patient was living in a home for the aged, and no treatment was instituted. given a diet of C. 150 grams, P. 70 grams, F. 85 grams, and 13 days later the carbohydrate was increased to 200 grams. On this diet and 30 to 36 units of insulin daily in divided doses the urine became free from sugar within one week. The insulin was then progressively decreased to a single morning dose of 10 units. It should be noted that the insulin requirement fell in spite of a moderate fever of unknown origin and an increase in carbohydrate from 150 to $200 \mathrm{grams}$. Attempts to decrease the insulin to 5 units on October 25 and October 26 resulted in the appearance of $9 \mathrm{grams}$ of sugar in the urine on each of these two days. During the last two weeks of this period the patient gained only 0.7 gram of hemoglobin and less than 400,000 red cells. Because of the inadequate hematological response we determined to re-

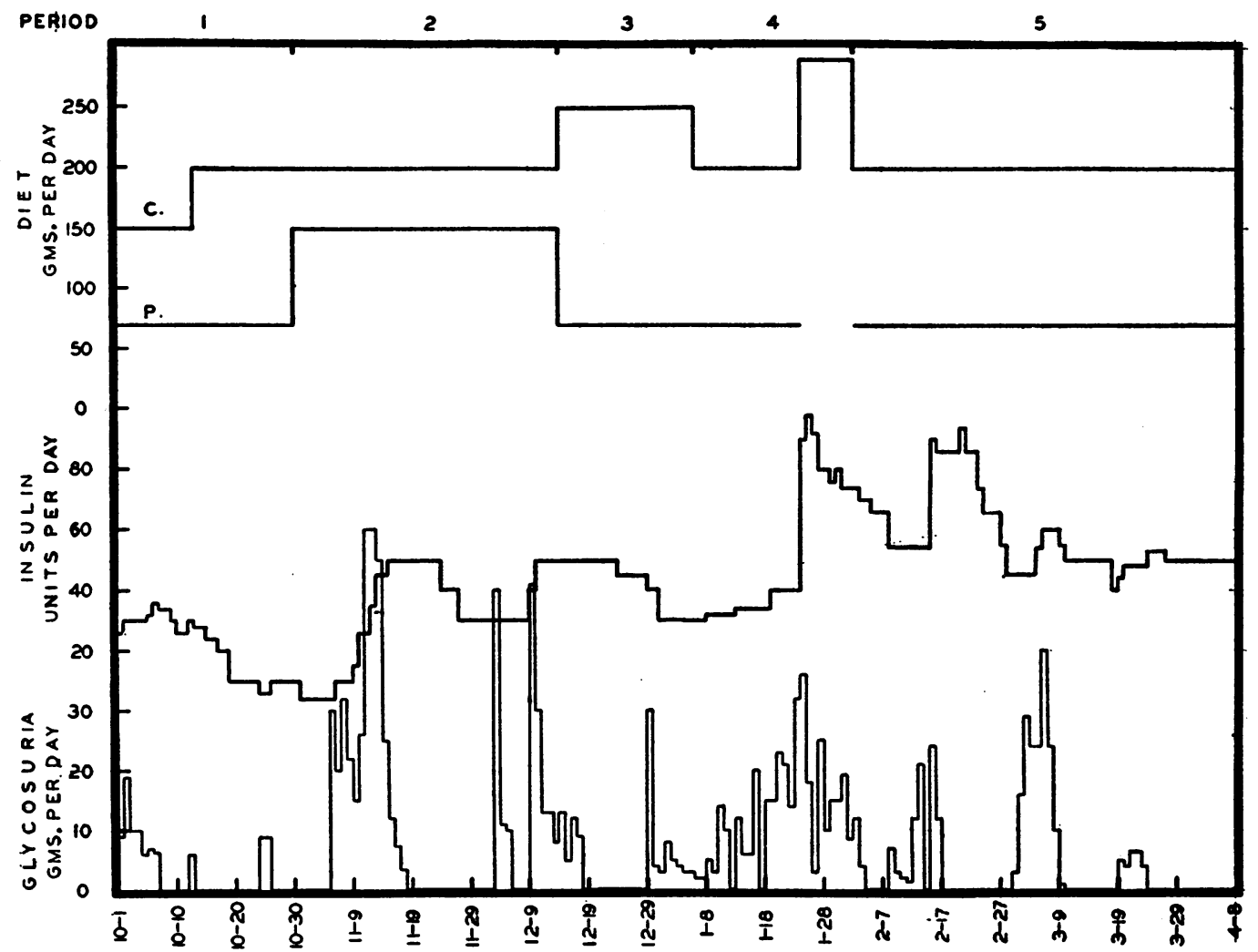

Fig. 1. Observations on Case I, M. K.

Liver therapy was instituted the day of admission, the patient receiving 3 cc. of Lederle's liver extract for parenteral use, containing the material derived from 100 grams of liver, on September 28, 29, and 30. An increase in reticulocytes followed, reaching a maximum of 11 per cent on October 3. From this point on the course of events can best be followed in stages, and by reference to Figure 1.

Period 1. During this 30 day period the patient received 1 gram of iron daily in the form of ferric ammonium citrate, and two injections each week of $3 \mathrm{cc}$. Lederle's liver extract for parenteral use. She was arrange her diet more in accordance with that given patients with uncomplicated anemia. This plan was carried out in Period 2.

Period 2. The diet given contained C. 200 grams, P. 155 grams, F. 85 grams, and parenteral liver and iron by mouth was continued as in Period 1 . During this period of $\mathbf{4 5}$ days a satisfactory hematological response was observed. The red cell count reached five million, and the hemoglobin 12 grams per $100 \mathrm{cc}$. on December 6,43 days following institution of the high protein diet. On the second day of this period, in spite of an increase of 49 grams in available carbohydrate, a mild reaction to 
insulin occurred. The dose of insulin was then reduced to $\mathbf{5}$ units daily. Five days later $\mathbf{3 0}$ grams of sugar appeared in the urine, and during the next 15 days, in spite of constantly increasing amounts of insulin, moderate glycosuria continued. To make the urine sugar free $\mathbf{5 0}$ units of insulin were necessary. This dosage of insulin was continued for six days in which no glycosuria or insulin reactions occurred. On November 24 the dose was reduced to 40 units daily, and on November 27 to 30 units daily. On December 3 about 35 grams of sugar was found in the urine, and about 10 grams on the next two succeeding days. Glycosuria ceased for three days, and then recurred, necessitating an increase in insulin to 40 units on December 9 and to 50 units on December 10. This amount of insulin failed to prevent glycosuria, about 10 grams of sugar having been found in the urine on December 14. We believed that this increase in severity of the diabetes could be attributed to the excess protein, and consequently the diet was changed to that in Period 3.

Period 3. The diet given contained C. 250 grams, P. 70 grams, F. 85 grams. This diet during a period of 23 days had the same carbohydrate equivalent per diem as the preceding high protein, and furnished 140 less total calories. The dose of 50 units of insulin was continued, and within four days glycosuria was absent. Insulin was gradually decreased to 30 units daily. On this diet and dosage of insulin, about 5 grams of sugar per diem appeared in the urine for the last five days of this period. We believe it probable that the insulin requirement would have decreased progressively had not the occurrence of fever ended this period.

Period 4. This period of infection lasted for 25 days. On January 8 a rhinitis developed, and although the patient was confined to bed a temperature of $101^{\circ}$ developed on January 11. No definite cause of the low grade fever could be determined. On January 24 a typical facial erysipelas developed, with fever of $105^{\circ}$. The diet was immediately changed to one consisting of almost pure carbohydrate. She received food every two hours day and night with a dosage of insulin depending on urinary findings taken prior to each feeding. The patient went through this severe infection without acidosis. The red cells fell to three million, in spite of transfusions of $500 \mathrm{cc}$. of whole blood on January 25, 26, and 27. On January 28 the erysipelas was fading, the insulin requirement diminishing, and the temperature subsiding, and by February 2 the patient was free of fever, at which time the diet of Period 5 was instituted.

Period 5. This period of readjustment of diet and insulin following infection continued over the next 60 days till discharge of the patient. She was given a diet containing C. 200 grams, P. 70 grams, F. 85 grams. On this diet 90 units of insulin per diem, in divided doses, were required at first to control glycosuria. We were able gradually to reduce the dosage of insulin, but at no time could it be decreased below 50 units daily without the appearance of glycosuria, as shown in Figure 1, between February 27 and March 9, and March 19 to March
24. We lost track of this patient following discharge and are therefore unable to make a report of the course of events subsequently.

\section{Case II}

R. G., an unmarried Russian Jewess, 28 years old, was admitted for mental observation to the medical wards of the Bellevue Psychiatric Division on August 30, 1933. Examination showed a poorly nourished woman, appearing chronically ill, bedridden and with a moderate pallor. There was a smooth tongue, marked weakness of both lower extremities with absent tendon reflexes, absent postural and vibratory sense, and an extensor plantar response. The heart and lungs were normal. No viscera were palpable. Examination of the blood showed 8.8 grams hemoglobin per $100 \mathrm{cc}$. and 2.58 million red blood cells per cu. $\mathrm{mm}$. The color index was 1.0 , saturation index 0.80 , and the volume index 1.26 . The smear showed marked poikilocytosis and anisocytosis, and a number of oval macrocytes. The white blood cells numbered 5,800 , with a differential count as follows: polymorphonuclear leukocytes 70 , lymphocytes 28 , and monocytes 2 . The serum bilirubin was $0.74 \mathrm{mgm}$. per cent, and gave a delayed direct Van den Bergh reaction. Using the alcohol test meal, followed by histamine, no free hydrochloric acid could be demonstrated in the gastric contents. A postabsorptive blood sugar was $100 \mathrm{mgm}$. per cent. The urine was normal. Repeated stool examinations were negative for blood or parasites. Complete roentgenological study of the gastro-intestinal tract revealed it to be normal. It seemed probable that this patient had Addisonian pernicious anemia, but to obtain more evidence on this point the patient was treated by parenteral administration of a preparation of yeast; no reticulocyte response followed. On September 12 parenteral liver therapy was started; 3 cc. of Lederle's parenteral liver extract, containing the material derived from 100 grams of whole liver were administered for three successive days. An adequate reticulocyte response followed this procedure. Simultaneously with the reticulocyte response a marked change occurred in the patient. The delusions of identity disappeared; she became agreeable and cooperative, and ate the diet prescribed. Before the increase of reticulocytes the patient had to be fed through a tube. She had insisted volubly that she was the Czarina of Russia and had been kidnaped. Subsequently an adequate history was obtained, both from the patient and her family. The family history failed to reveal nervous or mental disease, anemia, or diabetes. Except that she had had the common childhood diseases the patient had been well till July, 1932, when she noted increasing weakness and fatigue, and difficulty in walking, accompanied by a loss of 25 pounds in weight. She had entered another hospital where a diagnosis of a microcytic hypochromic type of anemia was made. Mildly abnormal neurological signs were reported to have been present at that time. The postabsorptive blood sugar was $98 \mathrm{mgm}$. per cent, and the urine normal. She was treated with liver and iron and made a fair recovery, remaining well for a year. About the first of August, 
1933, the patient developed mental symptoms, weakness, fatigue, and a progressive inability to walk. After about a month the family, because they were unable to persuade the patient to eat, and because of her delusions of identity, brought her to the hospital for mental observation. marked tenderness was elicited in the right costovertebral triangle. The pyelitis rapidly cleared by the usual expectant treatment, and the temperature was normal by October 25 . There was a mild recurrence of fever from December 6 to 8, after which the patient was free of fever.

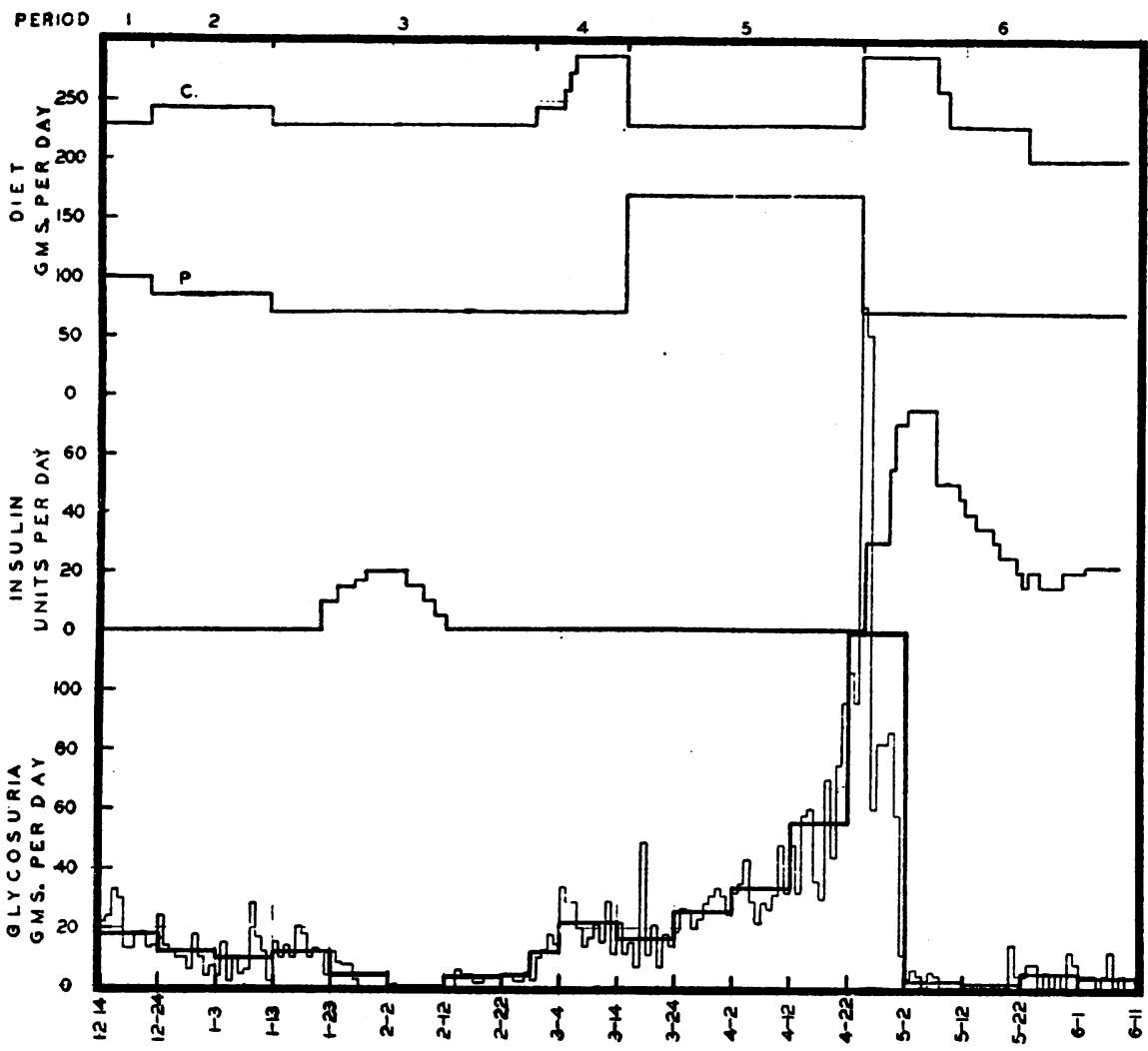

Fig. 2. Observations on Case II, R. G.

Following the rise of reticulocytes the patient was given a diet which was rich in protein and green vegetables, in addition to one-half pound of liver daily. Two parenteral injections of liver, each containing the material derived from 100 grams of liver, were given weekly, as well as 1 gram daily of iron by mouth. A satisfactory level of hemoglobin and red cells was reached by December 1, but on account of the marked neurological changes confining the patient to bed or a wheel chair hospitalization was continued. Parenteral administration of liver and iron by mouth was continued, as well as physiotherapy. One-half pound of liver daily was added to the high caloric, high protein diet for anemia.

On admission, August 30,1933, the patient had a temperature of $101^{\circ}$. The fever continued to run a low grade course till September 10, after which the temperature became normal. No adequate explanation can be offered for this period of fever. On October 15 the temperature suddenly rose to $102^{\circ}$. On the next day clumps of pus cells were discovered in the urine and
Casual urine specimens, nine in number, were negative for sugar till November 27, at which time a trace appeared; a morning specimen of urine on November 29 contained 0.5 per cent sugar; glycosuria was absent till December 8, when it recurred. On December 11 the fasting blood sugar was $131 \mathrm{mgm}$. per cent, rising to $172 \mathrm{mgm}$. two hours after breakfast. On December 14 the blood sugar was $175 \mathrm{mgm}$. per cent fasting, and 230 and $207 \mathrm{mgm}$. per cent two and three and one-half hours after breakfast respectively. The course of events with this patient can now best be followed in periods, and by reference to Figure 2.

Period 1. During this period of 8 days the diet contained C. 230 grams, P. 100 grams, F. 85 grams, and no insulin was given. This diet contained about one-half the amount of protein given in the unweighed anemia diet. The diabetes during this period was mild, as shown by the average daily excretion of 18 grams of urinary sugar, 278 grams of the 296 grams of carbohydrate available in the diet having been utilized.

Period 2. The diet during this period of 21 days was 
maintained isocaloric with that in Period 1 by decreasing the protein 15 grams and increasing the carbohydrate by 15 grams, making the dietary formula C. 245 grams, P. 85 grams, F. 85 grams. The carbohydrate equivalent was 6 grams more than that in Period 1. The amount of sugar in the urine decreased from an average of 18 grams to 13 grams for the first 10 days on this diet, and to 9 grams during the second 10 day period. This indicates the utilization of 289 and 293 of the 302 grams of available carbohydrate in the two consecutive 10 day periods, as compared with 278 grams dextrose available in Period 1.

Period 3. The patient in Period 2 had demonstrated the ability to utilize 289 grams of dextrose with a protein intake of 85 grams per diem. During the third period, of 46 days, the carbohydrate equivalent was reduced to 279 grams by reducing the carbohydrate and protein in the diet each by 15 grams, making the dietary formula C. 230 grams, P. 70 grams, F. 85 grams. The glycosuria continued at about 10 grams per diem. On January 20 , insulin was first given, 20 units being required to prevent glycosuria. We were then able to progressively reduce the insulin to 5 units daily without the recurrence of glycosuria. When administration of insulin was omitted entirely the average amount of sugar excreted daily was 2.5 grams during the last 15 days of this period. This degree of glycosuria was practically constant and showed no tendency to increase. This last period of 15 days seemed to us an adequate control period for an acute experiment, for we recognized that any change to be significant must be marked and definite.

Period 4. During this 16 day period the diet was changed to C. 290 grams, P. 70 grams, F. 85 grams. This increase of 60 grams in carbohydrate was accomplished over an eight day period. The addition of 60 grams of carbohydrate resulted in a daily average of 22 grams of sugar over a 10 day period. Here again there was no tendency for the glycosuria to increase over the last 10 days of this period.

Period 5. This period of high protein feeding lasted for 41 days. The extra 60 grams of carbohydrate added in Period 4 was omitted, and 100 grams of protein added, making the dietary formula C. 230 grams, P. 170 grams, F. 85 grams. The available carbohydrate of this diet was almost identical with that in Period 4 and was, for practical purposes, isocaloric. During the first 10 day period of this diet the average daily sugar excretion decreased to 17 grams from the daily average excretion of 22 grams for the last 10 days of Period 4. In the second 10 day period, from May 24 to April 2, the average daily excretion was 25 grams of sugar, and from this point on the severity of the diabetes progressed rapidly: The average from April 2 to April 12 was 33 grams; from April 12 to April 22, 55 grams. On April 22 and 23, 120 grams of sugar was found in the urine, and on April 24, 275 grams, accompanied by thirst and polyuria but no acetone bodies. The patient on this day utilized only 62 of the 337 grams of available carbo- hydrate in the diet. The patient was now returned to the diet in Period 4.

Period 6. The extra 100 grams of protein added to the diet in Period 5 was replaced by 60 grams of carbohydrate, making the dietary formula C. 290 grams, P. 70 grams, F. 85 grams. With this diet 75 units of insulin daily in four doses was required to reduce the glycosuria to an average of $\mathbf{5}$ grams daily. With the same diet in Period 4, without insulin, the patient excreted an average of 22 grams of sugar daily. Exogenous insulin probably accounted for the utilization of 150 grams of sugar, and with 5 grams appearing in the urine it may be calculated that this patient utilized over this five day period (May 2 to May 7) 184 of the 339 grams of available carbohydrate in the diet. The carbohydrate in the diet was then cut to 260 grams and, two days later, to 230 grams. Insulin dosage was gradually reduced to 25 units daily. At this point, 25 days after termination of the high protein diet, it may be calculated that the patient was utilizing 229 grams of the 279 grams of available carbohydrate in her diet. Attempts to reduce insulin below 25 units daily resulted in glycosuria. On the same diet without insulin in Period 4 an average of 2.5 grams of sugar appeared in the daily urine. On May 23, preparatory to discharge from the hospital, the carbohydrate in the diet was reduced to 200 grams. On this diet the insulin dosage was 22 units, with appearance of an average of 6 grams of urinary sugar from June 2 to discharge to a hospital for chronic diseases on June 11. The patient six months later was on a diet of C. 90 grams, P. 75 grams, F. 90 grams, and taking 30 units of insulin without glycosuria.

\section{COMMENT}

The addition of an excess of protein to the diet of these two individuals having pernicious anemia did not result in an immediate increase in severity of the diabetes. In M. K., following the addition of 80 grams of protein to her diet, a mild insulin reaction occurred on the second day, causing us to decrease the dose of insulin from 10 to 5 units daily. In R. G., the addition of 100 grams of extra protein and a simultaneous decrease in the carbohydrate of the diet by 60 grams was followed by a diminution in the daily excretion of urinary sugar for 10 days. The addition of excess protein to the diet in the cases reported by Gephart, Aub, DuBois and Lusk (6), Geyelin and DuBois (7), and by Wilder, Boothby and Beeler (8) resulted in the immediate increase in the severity of the disease. We believe it possible that the high carbohydrate content of the diet may have protected our patients from the immediate deleterious effects of the added protein. The carbohydrate content of the diets used by the 
previous observers was exceedingly low. In two instances only 3 grams or less of carbohydrate was allowed daily, and in the other 23.5 grams daily was permitted. In our cases, M. K. was allowed 200 grams, and R. G. 230 grams of carbohydrate at the time they were receiving the extra protein.

The ultimate result in our two cases of an excess of protein in the diet was deleterious. The influence of adding protein without otherwise changing the diet is effectively demonstrated in Periods 1,2 , and 3 in M. K. This patient demonstrated the ability to remain free of glycosuria when 10 units of insulin were given daily (Period 1) with a dietary formula of C. 200 grams, P. 70 grams, F. 85 grams. The addition of 80 grams of protein was followed by glycosuria on the fifth day, and in spite of progressively increasing the dose of insulin, glycosuria persisted for 15 days. The progressive nature of the impairment may be noted in that from November 19 to 25 the urine was sugar free when 50 units of insulin were given daily, but on the same amount of insulin, glycosuria was present from December 10 to 14. This also shows that the deleterious effect of an excess of protein was manifest in the absence of glycosuria. The 80 grams excess of protein, continued for $\mathbf{4 5}$ days, was followed by an increase of 40 units of insulin daily, which amount was not quite sufficient, at the end of the period, to prevent glycosuria. The extra 49 grams of carbohydrate made available by the 80 grams of protein required an increase of 40 units of insulin. On cutting the extra 80 grams of protein and substituting an equivalent amount of carbohydrate (Period 3) and maintaining the same amount of insulin, glycosuria was absent by the fifth day. Likewise it is to be noted that slight glycosuria does not preclude improvement in carbohydrate utilization. A progressive improvement occurred, so that by January 1,17 days after omitting the excess protein, the insulin requirement was 30 units, with only 2 to 8 grams of sugar in the daily 24 hour urine. We believe an increase in insulin of 3 to 5 units would have made the urine sugar free at this stage. We believe this patient would have continued to improve had not Period 3 been interrupted by a severe infection. Our data on this patient from this time can not be used to study the effect of protein.

The deleterious effect of an excess of protein was not minimized by a reduction in the carbohydrate of the diet equivalent to the available dextrose in the protein. This is demonstrated in the case of R. G. (Periods 4, 5, and 6). In Period 3 the patient demonstrated an ability to utilize a diet of C. 230 grams, P. 70 grams, F. 85 grams without insulin with an average of only 3 grams of sugar in the urine over a 15 day period (February 12 to 27). In Period 4 the carbohydrate over a week's time was increased by 60 grams to 290 grams with an average excretion over a 10 day period (April 4 to 14) of 22 grams of sugar. There was no indication during this period that the glycosuria was increasing. The 60 grams of extra carbohydrate was replaced by 100 grams of protein containing the same amount. of available carbohydrate. Following the first 10 day period in which the average sugar excretion slightly decreased, there was a progressive and constantly increasing glycosuria. Between the 30th and 40th day the average daily glycosuria amounted to 75 grams, indicating that the patient was now utilizing 262 of the 337 grams of available carbohydrate in her diet. At this point the daily urine volume suddenly increased (April 22) to be followed by 140 grams of urinary sugar on April 22, and 275 grams on April 23. Due to the marked glycosuria and diuresis, with loss of serum electrolytes in the urine, we felt that it was no longer safe to continue this diet. Consequently, in Period 6, the 100 grams of protein was replaced by 60 grams of carbohydrate, and insulin given. At this time, May 6 . the patient required 75 units of insulin to prevent glycosuria. Probably this exogenous insulin utilized 150 grams of carbohydrate, indicating that this patient was utilizing 189 grams of the 339 grams of available carbohydrate in her diet. Within 13 days, therefore, after discontinuing the high protein diet the carbohydrate tolerance of the patient had increased from 112 to 189 grams. During the next 10 days the improvement was more rapid, so that 25 days after discontinuing the excess protein the patient was utilizing 229 of the 279 grams of available carbohydrate in her diet. This is the last available accurate calculation of tolerance, for when we reduced her diet 
to C. 200 grams, P. 70 grams, F. 85 grams the patient surreptitiously obtained food.

The deleterious effect of protein on the carbohydrate tolerance remains for some time after a return to a high carbohydrate, low protein-fat diet. In 25 days patient R. G. had a tolerance for 229 of 279 grams of available carbohydrate in her diet, while prior to the high protein period her tolerance was 317 of the 339 grams of available carbohydrate. Six months following discharge this patient had regained but little of her original tolerance. Patient M. K. in 25 days following cessation of the period with extra protein utilized 234 grams of 299 grams available, while prior to the high protein period she utilized 229 of 249 grams of available carbohydrate. These figures, while roughly giving one the degree of severity of the disease, are not strictly accurate unless the carbohydrate content of the diets in the two periods are similar. Increasing the amount of available carbohydrate in the diet, provided the increase is by additional carbohydrate rather than protein, often results in an increase in the total sugar utilized. R. G., February 12 to 27 , utilized 294 grams of 299 grams available; and with no change in status other than the addition of 60 grams of carbohydrate to the diet utilized, in the period from March 6 to 14, 337 grams of the 359 grams available.

The deleterious effect of a high protein diet remains and is progressive when marked or long continued glycosuria is prevented, and even occurs when glycosuria is absent. M. K., during the high protein diet, was prevented from showing large amounts of glycosuria by constantly increasing dosage of insulin. For 14 days, November 4 to 18, glycosuria was present, but not marked nor accompanied by polyuria. From November 19 to December 2 this patient was absolutely sugar free. Nevertheless this patient showed as much impairment of carbohydrate tolerance as R. G., who was allowed uncontrolled glycosuria.

\section{SUMMARY AND CONCLUSIONS}

We have studied two subjects having combined pernicious anemia and diabetes over six and nine months of hospitalization. One patient entered the wards in a state of severe diabetic ketosis and in a relapse of the anemia. The other patient en- tered the wards in a relapse of the anemia and with many psychotic manifestations. Following treatment for the anemia by parenteral injection of liver extract, iron by mouth, and high caloric, high protein diet over a three month period, diabetes developed. The carbohydrate tolerance of both patients was studied on low and high protein diets, with the following conclusions:

1. High protein diets in our two cases markedly reduced the carbohydrate tolerance. This reduction in tolerance cannot be explained by either an increase in calories or by the extra carbohydrate made available from the excess protein.

2. A simultaneous high carbohydrate diet apparently prevented the immediate deleterious effects of the excess protein becoming apparent. Ultimate results were qualitatively similar to that observed in previous studies when low carbohydrate diets were employed.

3. The loss of carbohydrate tolerance as a result of the high protein diet is not temporary. The tolerance remained impaired in one subject for at least 25 days, and in the other for at least six months.

4. Insulin, when given in amounts sufficient to prevent either long continued or severe glycosuria, does not ward off the deleterious effect of excess protein in the diet.

\section{BIBLIOGRAPHY}

1. Root, H. F., New cases of combined pernicious anemia and diabetes. New England J. Med., 1933, 208, 819.

2. Greenwald, I., Gross, J., and Samet, J., The nature of the sugar in normal urine. II. The sugar excretion upon various diets and the influence of diet upon glucose tolerance with some remarks on the nature of the action of insulin. J. Biol. Chem., 1924-25, 62, 401.

Sweeney, J. S., Dietary factors that influence the dextrose tolerance test. Arch. Int. Med., 1927, 40, 818.

Malmros, H., A study of glycosuria with special reference to the interpretation of the incidental finding of a positive reduction test. Acta med. Scandinav., 1928, Suppl. 27, 1.

Heinbecker, P., Studies on the metabolism of Eskimos. J. Biol. Chem., 1928, 80, 461.

Tolstoi, E., The effect of an exclusive meat diet lasting one year on the carbohydrate tolerance of two normal men. J. Biol. Chem., 1929, 83, 747.

Himsworth, H. P., Dietetic factors influencing the glucose tolerance and the activity of insulin. J. Physiol., 1934, 81, 29. 
3. Joslin, E. P., The Treatment of Diabetes Mellitus. Lea and Febiger, Philadelphia, 1928, 4th ed.

4. Falta, W., and Gigon, A., Ueber Empfindlichkeit des Diabetikers gegen Eiweiss und Kohlehydrat. Verhandl. d. Kongress f. inn. Med., 1907, 24, 256.

5. Klemperer, G., Die Verwertung reinen Traubenzuckers bei schweren Diabetikern. Therap. d. Gegenw., 1911, 52, 447.

6. Gephart, F. C., Aub, J. C., DuBois, E. F., and Lusk, G., Clinical calorimetry. XXIV. Metabolism in three unusual cases of diabetes. Arch. Int. Med., 1917, 19, 908.

7. Geyelin, H. R., and DuBois, E. F., A case of diabetes of maximum severity with marked improvement. A study of blood, urine, and respiratory metabolism. J. A. M. A., 1916, 66, 1532.

8. Wilder, R. M., Boothby, W. M., and Beeler, C., Studies of the metabolism of diabetes. J. Biol. Chem., 1922, 51, 311.

9. Lusk, G., The Elements of the Science of Nutrition, W. B. Saunders, Philadelphia, 1928, 4th ed.

10. Schloss, J., Uber die Bedeutung von Fett und Eiweiss für die Diätbehandlung des Diabetes
Mellitus. I. Vergleichende Beobachtungen an fettarmen und eiweissarmen Zweinährstoffkombinationen. Deutsches Arch. f. klin. Med., 1932, $173,657$.

11. Schloss, J., Uber die Bedeutung von Fett und Eiweiss fur die Diätbehandlung des Diabetes Mellitus. II. Blutzuckertageskurve und Harnzuckertageskurve bei fettarmen und eiweissarmen Zweinahrstoffkombinationen. Ztschr. f. klin. Med., 1933, 125, 641.

12. Von Noorden, C., Metabolism and Practical Medicine, Vol. I. W. T. Keener and Co., Chicago, 1907.

13. Woodyatt, R. T., Objects and method of diet adjustment in diabetes. Arch. Int. Med., 1921, 28, 125.

14. Newburgh, L. H., and Marsh, P. L., The use of a high fat diet in the treatment of diabetes mellitus. First Paper. Arch. Int. Med., 1920, 26, 647.

Ibid., Second paper. Blood sugar. Arch. Int. Med., 1921, 27, 699.

Ibid., Further observations on the use of a high fat diet in the treatment of diabetes mellitus. Arch. Int. Med., 1923, 31, 455. 